\title{
Species richness of thrips and whiteflies and their predators in mustard fields
}

\author{
S. Das, M. M. Rahman ${ }^{1}$, M. M. Kamal* and A. Shishir \\ Agrotechnology Discipline, Khulna University and ${ }^{1}$ Bangladesh Agricultural Research Institute (BARI), Gazipur, \\ Bangladesh, *E-mail: mostofaku@gmail.com
}

\begin{abstract}
With a view to assessing the effect of temperature $\left({ }^{\circ} \mathrm{C}\right)$ and locations on species richness of thrips and whiteflies and their natural enemies (NEs), predatory Geocoris bug and Asian lady bug beetle (LBB) in mustard field of BARI Sarisha 16, the experiment was carried out at the farmers' fields in two specific locations of Southern Bangladesh, Rupsha, Khulna and Abhaynagar, Jessore during November, 2015 to March, 2016. The studies were laid out with randomized complete block deign (RCBD) maintaining four replicates. The results depicted that there was a significant variation in mean population abundance of thrips, whitefly and their predators across the observation dates, which principally resulted from the variation of temperature along the various observation dates in each location and between locations along with phenological characters of host plants. Initially, population of thrips and whitefly, and their predators were very low in both locations at first observation date of 20 November, 2015 which gradually colonized and reached the peak in 19 March, 2016 with temperature of $27.8^{\circ} \mathrm{C}$ and $71 \% \mathrm{RH}$ in $\mathrm{Khulna}$ and $26.1^{\circ} \mathrm{C}$ and $61 \% \mathrm{RH}$ in Jessore. Notably, temperature ranging from $22-27^{\circ} \mathrm{C}$ during mid-February to March, 2016 considerably favors the species richness of both insect pests, thrips and whiteflies, and their predators, Geocoris bug and Asian lady bug beetle in both places. By contrast relative low temperature of $16-20^{\circ} \mathrm{C}$ from December 20,2015 to January 29, 2016 affected the species richness of predators and pest as well. The yield of mustard, BARI Sarisha 16 was significantly higher in Jessore $\left(1365.75 \mathrm{kgha}^{-1}\right)$ due to lower pest population and higher predator population relative to Khulna region $\left(1277.25 \mathrm{kgha}^{-1}\right)$. Ecological factors especially temperature appeared as major striking factor of species richness and played crucial role in getting up and down of mustard insect pests and NEs population across various date of observations and between places.
\end{abstract}

Keywords: Species richness, Mustard, Thrips and Whitefly, Predators, Temperature

\section{Introduction}

Mustard (Brassica sp.) is one of the most dominant edible oilseed crops and positioned $2^{\text {nd }}$ after soybean across the globe. In Bangladesh, this oilseed crop alone occupies around $80 \%$ of the entire oilseed lands quantifying 325.05 thousand hectares and yields about $40 \%$ of the total oilseed production amounting around 360.00 thousand tons annually (BBS, 2015). The mustard seed yield $\left(0.95 \mathrm{t} \mathrm{ha}^{-1}\right)$ is quite low in our country relative to other oilseeds growing countries in the earth. The crop has experienced enlargement in area and production over time along with facing fierce competition of land for cultivation of cereals namely rice, wheat and maize (Miah et al., 2010). Bangladesh is currently producing around 0.36 million tons of edible oil every year against the national annual requirement of 1.4 million tons (Mallik, 2013). Our domestic production meets only $21 \%$ of our consumption and the remaining $79 \%$ comes through import $(F A O, 2011)$ that regularly incurs a vast amount of foreign exchange to spend every year.

There are several important factors associated with the low yield of mustard such as diseases, pest, ecology, etc. of which insect pests' infestation and temperature are the key determinants. Mustard is a cold season oilseed crop whose yields considerably varies with variation in temperature. In winter season mustard crops used to confront a lot of insect prevalence, especially piecing sucking insects named whitefly, thrips and aphid reducing the crop vigor and yield potential. To control those pests, the growers principally depends on synthetic chemicals which are most often overused or misused resulting in death of both harmful insects and their natural enemies, predatory insects such as Asian lady bug beetle, Geocris bugs, and spiders. In uninterrupted agroecosystem with no insecticides usage, the natural enemies feed on the soft bodied harmful insect pests and prevent the pest richness from reaching the economic injury level and thus offer a solid foundation of ecofriendly management system of mustard pests for mustard growers (Furlong et al., 2008; Syed et al., 2016). 
Whiteflies and thrips have piercing sucking type mouthparts and absorb the cell sap from the mustard body parts especially leaf, tender stem, axillary buds and siliqua causing poor growth, vigor and yield resulting great economic loss. These insects not only damage the oilseed crop by direct feeding on foliage, flowers or fruits but also vector different viral diseases as well. The common host crops of whiteflies and thrips are cotton, cucumber, onion, tomato, potato, tobacco, cabbage, and ornamental plants. Thrips (Thysanoptera: Thripidae) causes serious damage on cultivated crops, mainly of family Alliaceous (e.g., onion and garlic) (Naultet al., 2006) and Whiteflies (Homoptera: Aleyrodidae) are amongst the key pests of vegetable, ornamental and agronomic crops throughout the world (Liu, 2000) and both are polyphagous in nature. The two major devastating species of whitefly are the silver leaf whitefly, Bemisiatabaci (Gennadius) and the greenhouse whitefly, Trialeurodes vaporariorum (Ramsey et al., 1994). The use of natural enemies is one of the safest methods of pests control since this is not toxic, pathogenic or injurious to humans. Big-eyed bugs Geocoriss pp., (Hemiptera: Lygaeidae) and Asian lady bug beetle (Coleptera: Coccinellidae) are used as efficient biocontrol agents of whitefly and thrips in different parts of the world (Messelink et al., 2008). Both larvae and adults are predacious and live on available prey population. However, alongside ecological factors, the richness of both harmful insect as well as their natural enemies considerably impact the mustard yield. Therefore, the present field studies are designed to assess the natural insect pest pressure and predators' richness in mustard fields in two regions of Bangladesh in order of comparing mustard yield under variable environmental conditions.

\section{Materials and Methods}

The present field studies were carried out in two distinct locations of Bangladesh; Rupsha, Khulna and Abhaynagar, Jessore during November, 2015 to March, 2016 to assess the effect of temperature and location on the species richness of thrips and whitefly pests, and their natural enemies of predatory Geocorisbug and Asian lady bug beetle impacting mustard yield (Brassica campestris L.) of BARI Sarisha 16.

Mustard variety namely, BARI Sarisha 16 was grown in November, 2015 in a Completely Randomized Block Design with four replications, each replicate's subplot size of the study in each location was $20 \times 10$ square meter, maintaining an isolation distances of 2 feet between subplots. All agronomic practices were done to grow the crop as and when necessary. The population abundance of thrips and whitefly, and their natural enemies, Geocoris bug and Asian lady bug beetle were counted at the interval of 10 days. Thirty plants were randomly selected from each subplot, therefore $30 \times 4=120$ plants from each location and then five leaves were selected at random, two from bottom, two from middle and one from top, and finally the population of thrips and whitefly pests and natural enemies were counted visually with magnifying glass. The plants were carefully handled to avoid interrupting the whitefly and thrips, and their natural enemies of predatory Geocoris bug and Asian lady bug beetle on the plants. Time of visual observation was $8.00 \mathrm{am}-10.30 \mathrm{am}$ and notably, no pesticide was applied in or around the study field. Three types of mustard yield were taken in the study, plant yield $\left(\mathrm{g} \mathrm{plant}^{-1}\right)$, biological yield $\left(\mathrm{kg} \mathrm{ha}^{-1}\right)$ and seed yield $(\mathrm{kg}$ $\left.\mathrm{ha}^{-1}\right)$. Temperature and humidity data for the study period were validated from respective agrometeorological stations in Khulna and Jessore.

\section{Statistical analysis}

Data were analyzed using JMP statistical package to determine variance among the observational treatments while mean differences were evaluated with Turkey-HSD test.

\section{Results and Discussion}

The experiments were conducted to determine the species richness of thrips and whitefly and their predators, Geocoris spp. and Asian lady bug beetle, at two different localities of Khulna and Jesssore with variable temperature $\left({ }^{\circ} \mathrm{C}\right.$ ) and relative humidity, $\mathrm{RH}(\%)$. The richness or abundance of the insect pests and their predators was estimated for upper five leaves of each sample mustard plant (BARI Sarisha 16) through visual observation with magnifying glass at the interval of 10 days from November, 2015 to March, 2016 (Table 1). 


\section{Species richness in Khulna region}

The results revealed that mean species richness of thrips and whitefly, and their predators on mustard varied significantly with different dates and phenology of plant in the demonstration field of Rupsha, Khulna. Initially, the population richness of thrips was recorded to be very low (4.33 thrips plant ${ }^{-1}$ ) in early vegetative growth stage of mustard on November 20,2015 with $25^{\circ} \mathrm{C}$ and $77 \% \mathrm{RH}$. After settling down the less number of thrips started colonizing through multiplication that resulted in increased population richness over time and reached the peak of 72.50 thrips plant ${ }^{-1}$ on March19, 2016 with $27.8^{\circ} \mathrm{C}$ and $71 \%$ $\mathrm{RH}$. The identical findings were reported by Bjorn (1995) for thrips infesting winter white cabbage, and Nault et al. (2006) for onion thrips in New York onion field. The relative thrips richness in mustard on March, 2016 was statistically different from that in February 18, 2016 to November, 2015 that might be due to fluctuation in temperature and humidity across the months studied along with predators-prey interaction even though the higher richness of thrips from February 18 to march 19, 2016 was statistically similar (Table 1).

Likewise, the primary richness of whitefly was very low $\left(2.32\right.$ whiteflies plant $\left.^{-1}\right)$ in the same field on November 20,2015 with $25^{\circ} \mathrm{C}$ and $77 \% \mathrm{RH}$. Over time the population increased and the highest whitefly richness was recorded (27.67 whiteflies plant ${ }^{-1}$ ) on March 19,2016 with $27.8^{\circ} \mathrm{C}$ and $71 \% \mathrm{RH}$. The richness of whiteflies population varied significantly over time from November, 2015 to March, 2016 for variable temperature and humidity. Earlier study also reported that the intrinsic rates of natural increase for silver leaf whitefly, $B$. argentifolii are greatly affected by temperature and the highest growth rate was found between 25 to $27^{\circ} \mathrm{C}$ (Wang and Tsai, 1996) which is almost identical to our study temperature from February 18 to March 19, 2016 where maximum richness of whiteflies was recorded. The analogous result was also reported by Ramsey et al. (1996) for cabbage whiteflies. Besides, the results explored that the whiteflies richness was statistically similar from December 30, 2015 to January 29, 2016 although their population size increased steadily (Table 1). The present results are in accordance with those of Liu (2000), who noted that the population of whitefly adults and immatures varied greatly with temperature.

The study results also showed the same trend of predators increase over time. At starting point, their population was very low (1.50 predators plant $^{-1}$ ) on November 20, 2015 but their higher population richness was recorded on March 19, 2016. The population richness of predators (Geocoris bug and Asian lady bug beetle) differed significantly across the various observation dates except few exceptions where there was no statistically significant change in predator richness from January 19 to February 28, 2016 (Table 1). The variation in predator richness may result from variable temperature and humidity, and prey density along with their dispersal and multiplication efficiency. Temperature is one of the most influential factor in predators' survival, development and reproduction, and most important lypredator-prey interaction strengths triggering their preying efficiency (Sentis et al., 2012).

The population richness of all species, thrips, whiteflies and predators was low at initial stage of crop growth which gradually colonized and reproduced into abundant progenies over time leading to high population abundance in host crop. The ecological factors especially temperature play key role in insect reproduction, and multiplication causing variation in their abundance (Bale et al., 2002) in consideration with other factors like host-insect interaction, host plant quality and crop density and canopy architecture. Host plant quality is a key determinant of the oviposition of herbivorous insects that directly affects insect reproductive phases such as egg size and quality, the allocation of resources to eggs, and the choice of oviposition sites (Awmack and Leather, 2002).

The regression analysis (Fig. 1) established the overwhelming evidence that temperature $\left({ }^{\circ} \mathrm{C}\right.$ ) greatly affect the population richness of thrips, whiteflies and predators. Thrips regression line reported that unit increase in temperature in $x$ axis yielded 3.75 unit rise in their population richness which signified the temperature upsurge up to a certain point positively impacted the thrips population to get increased. Murai (2000) documented that among five temperatures, $15^{\circ} \mathrm{C}, 20^{\circ} \mathrm{C}, 23^{\circ} \mathrm{C}, 25^{\circ} \mathrm{C}$ and $30^{\circ} \mathrm{C}$ onion thrips reproduced more than $80 \%$ at temperatures between 20 and $25^{\circ} \mathrm{C}$, it was low at $30^{\circ} \mathrm{C}$ and below $15^{\circ} \mathrm{C}$ but the fecundity was the highest at $23^{\circ} \mathrm{C}$ and the intrinsic rate of increase was highest at $25^{\circ} \mathrm{C}$ that is very parallel to our findings. Similarly, whiteflies increased at rate of 1.25 unit with unit temperature rise after $17^{\circ} \mathrm{C}$. Predator also followed the same trend of population increase $(0.81$ unit rise for unit rise in temperature) but their rate of rise was distinctly lower than thrips and whiteflies, respectively. 
Table 1. Population richness of thrips and whitefly, and predators, Geocoris spp. and Asian lady bug beetle, in mustard field at Rupsha, Khulna from November 2015 to March 2016

\begin{tabular}{l|ccc|c|c}
\hline \multirow{2}{*}{ Observations } & \multicolumn{3}{|c|}{ Population Richness } & Temperature & Humidity (\%) \\
& Thrips & Whiteflies & Predators & ( $\left.{ }^{\circ} \mathbf{C}\right)$ & \\
\hline 20 Nov 2015 & $4.33 \mathrm{~h}$ & $2.32 \mathrm{~h}$ & $1.50 \mathrm{~g}$ & 25.0 & 77 \\
30 Nov 2015 & $6.17 \mathrm{~h}$ & $3.83 \mathrm{gh}$ & $2.50 \mathrm{~g}$ & 23.9 & 78 \\
10 Dec 2015 & $10.17 \mathrm{gh}$ & $7.17 \mathrm{gh}$ & $3.00 \mathrm{fg}$ & 22.2 & 77 \\
20 Dec 2015 & $17.67 \mathrm{~g}$ & $9.08 \mathrm{fg}$ & $4.00 \mathrm{efg}$ & 20.0 & 75 \\
30 Dec 2015 & $29.83 \mathrm{f}$ & $13.17 \mathrm{ef}$ & $5.50 \mathrm{efg}$ & 18.9 & 78 \\
09 Jan 2016 & $39.67 \mathrm{e}$ & $15.00 \mathrm{de}$ & $6.83 \mathrm{def}$ & 22.2 & 80 \\
19 Jan 2016 & $44.83 \mathrm{de}$ & $15.67 \mathrm{de}$ & $8.08 \mathrm{cde}$ & 20.5 & 68 \\
29 Jan 2016 & $50.00 \mathrm{~cd}$ & $18.75 \mathrm{cde}$ & $9.83 \mathrm{bcd}$ & 21.1 & 78 \\
08 Feb 2016 & $54.00 \mathrm{c}$ & $19.67 \mathrm{bcd}$ & $9.83 \mathrm{bcd}$ & 22.2 & 71 \\
18 Feb 2016 & $58.00 \mathrm{bc}$ & $21.83 \mathrm{bc}$ & $9.95 \mathrm{bcd}$ & 26.6 & 66 \\
28 Feb 2016 & $66.17 \mathrm{ab}$ & $23.33 \mathrm{abc}$ & $12.33 \mathrm{abc}$ & 25.5 & 76 \\
09 March 2016 & $67.33 \mathrm{a}$ & $25.00 \mathrm{ab}$ & $14.00 \mathrm{ab}$ & 28.9 & 72 \\
19 march 2016 & $72.50 \mathrm{a}$ & $27.67 \mathrm{a}$ & $15.67 \mathrm{a}$ & 27.8 & 71 \\
\hline P value & $\mathbf{0 . 0 0 1}$ & $\mathbf{0 . 0 0 1}$ & $\mathbf{0 . 0 0 1}$ & - & - \\
\hline
\end{tabular}

*Means in columns followed by similar letters are non-significant

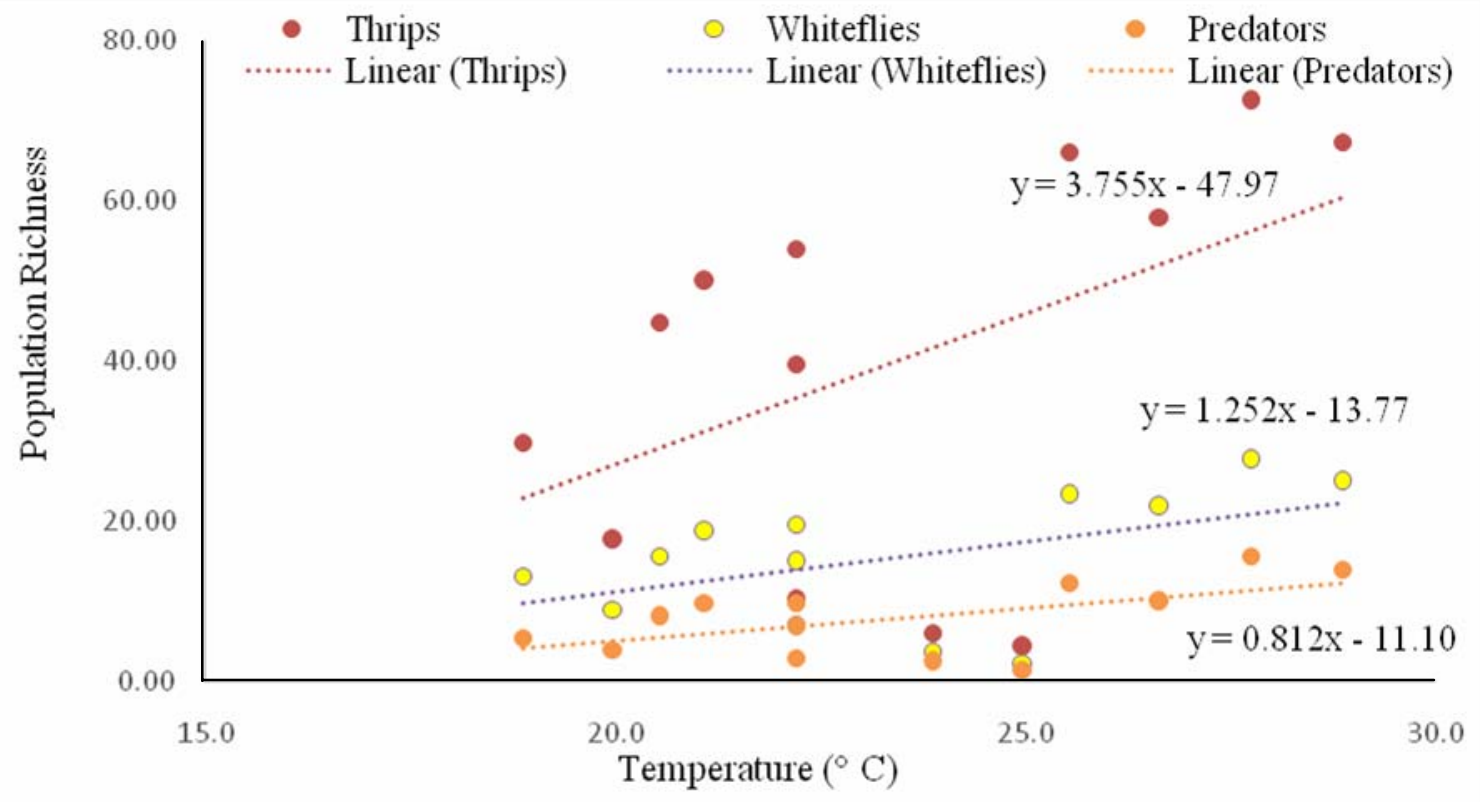

Fig. 1. Effect of temperature $\left({ }^{\circ} \mathrm{C}\right)$ on the population richness of insects in Khulna Region

\section{Species richness in Jessore region}

The results on population richness of thrips and whitefly, and their predators, Geocorisspp. and Asian lady bug beetle on mustard (BARI Sarisha 16) in Jessore, are presented in Table 2. The analysis pointed that population richness of those insect species varied significantly across the various observation dates from November 20, 2015 to March 19, 2016 with variable temperature $\left({ }^{\circ} \mathrm{C}\right)$ and humidity $(\%)$. In Jessore the maximum thrips' population was (66.33 thrips plant $^{-1}$ ) recorded in reproductive phase of mustard on March 19, 2016 with the temperature of $26.1^{\circ} \mathrm{C}$ and humidity of $61 \%$, and minimum richness (2.50 thrips plant $^{-1}$ ) was noted in early stage of crop growth on November 20,2015 with $24.4^{\circ} \mathrm{C}$ and $76 \% \mathrm{RH}$. The similar trend was also noticed in population abundance of whiteflies. During initial establishment in mustard plots, they were low in richness (1.32 whiteflies plant ${ }^{-1}$ ) and ultimately attained significantly higher abundance (1.32 24.83 whiteflies plant ${ }^{-1}$ ) in March with $26.1^{\circ} \mathrm{C}$ and $61 \% \mathrm{RH}$. The analysis also 
documented that predator richness was significantly lower (1.33 predators plant ${ }^{-1}$ ) in November, 2015 during early vegetative growth stage of mustard and higher (16.92 predators plant ${ }^{-1}$ ) in March 19, 2016 during reproductive phase of the crop. Predators' abundance increased with the rise of herbivore prey population on which the carnivore predators live on and prevent the pest population density from reaching the economic injury level (Dixon, 2000). The predator, ladybird Coccinella septempunctata L. condiderably successfully reduced the population richness of thrips, Thripstabaci Lindeman, and whiteflies, Trialeurodes vaporariorum (Westwood) on tomato leaves in controlled environmental condition with predator-prey ratio of1: 30 . Besides, the study reported that lady bird beetle' prefer preying $T$. tabacito $T$. vaporariorum (Deligeorgidis et al., 2005). The study findings strongly support the present research results of predator-prey responses in mustard field. Malik et al. (2012) reported that four predatory species especially lady bird beetle and spider richness were lower with low population density of mustard insect pests, whitefly, aphid and thrips in different mustard varieties throughout the growing season which corresponds the present study.

Table 2. Population richness of thrips and whitefly, and predators, Geocoris spp. and Asian lady bird beetle, in mustard at Abhaynagar, Jessore from November 2015 to March 2016

\begin{tabular}{l|c|c|c|c|c}
\hline \multirow{2}{*}{ Observations } & \multicolumn{3}{|c|}{ Population Richness } & Temperature ( $\left.{ }^{\circ} \mathrm{C}\right)$ & Humidity (\%) \\
\cline { 2 - 4 } & Thrips & Whiteflies & Predators & & 76 \\
\hline 20 Nov 2015 & $2.50 \mathrm{~h}$ & $1.32 \mathrm{~g}$ & $1.33 \mathrm{f}$ & 24.4 & 78 \\
30 Nov 2015 & $4.67 \mathrm{~h}$ & $2.83 \mathrm{~g}$ & $2.00 \mathrm{f}$ & 23.3 & 75 \\
10 Dec 2015 & $7.33 \mathrm{gh}$ & $5.67 \mathrm{fg}$ & $2.50 \mathrm{f}$ & 22.2 & 62 \\
20 Dec 2015 & $13.50 \mathrm{~g}$ & $6.25 \mathrm{fg}$ & $3.83 \mathrm{ef}$ & 17.2 & 72 \\
30 Dec 2015 & $26.50 \mathrm{f}$ & $9.50 \mathrm{ef}$ & $6.50 \mathrm{def}$ & 17.8 & 72 \\
09 Jan 2016 & $34.67 \mathrm{ef}$ & $12.83 \mathrm{de}$ & $7.83 \mathrm{de}$ & 20.0 & 67 \\
19 Jan 2016 & $40.50 \mathrm{de}$ & $13.17 \mathrm{cde}$ & $9.08 \mathrm{~cd}$ & 18.9 & 85 \\
29 Jan 2016 & $45.33 \mathrm{~cd}$ & $16.50 \mathrm{bcd}$ & $9.58 \mathrm{~cd}$ & 16.7 & 75 \\
08 Feb 2016 & $49.33 \mathrm{c}$ & $16.50 \mathrm{bcd}$ & $9.67 \mathrm{bcd}$ & 21.1 & 69 \\
18 Feb 2016 & $53.00 \mathrm{bc}$ & $18.33 \mathrm{bc}$ & $11.67 \mathrm{bcd}$ & 26.6 & 72 \\
28 Feb 2016 & $59.83 \mathrm{ab}$ & $19.33 \mathrm{~b}$ & $14.00 \mathrm{abc}$ & 25.5 & 64 \\
09 March 2016 & $62.17 \mathrm{a}$ & $21.75 \mathrm{ab}$ & $14.83 \mathrm{ab}$ & 27.8 & 61 \\
19 march 2016 & $66.33 \mathrm{a}$ & $24.83 \mathrm{a}$ & $16.92 \mathrm{a}$ & 26.1 & - \\
\hline P value & $\mathbf{0 . 0 0 1}$ & $\mathbf{0 . 0 0 1}$ & $\mathbf{0 . 0 0 1}$ & - \\
\hline
\end{tabular}

*Means in columns followed by similar letters are non-significant

The regression analysis indicated that environmental factors especially temperature had a considerable impact on the population abundance of harmful insect pests, thrips and whiteflies, and their natural enemies, Geocoris bug and Asian lady bird beetle in mustard filed in Jessore (Fig. 2). Thrips population abundance climbed up at a rate of 2.19 individuals with expense of every unit increase in temperature $\left({ }^{\circ} \mathrm{C}\right)$ from 16 to $28{ }^{\circ} \mathrm{C}$. By contrast, the rate of increase in whiteflies' richness was 0.73 individuals with unit increase in temperature while the predators' abundance rose at 0.57 rate with rise of every ${ }^{\circ} \mathrm{C}$.

However, the variation of rate of increase in population abundance of insect pests and predators between two regions, Khulna and Jessore was principally due to distinct variation in temperature $\left({ }^{\circ} \mathrm{C}\right)$ along with predator-prey response and host plant phenological characteristics. The statistical analysis revealed that predator population of Geocoris bug and Asian lady bug beetle was higher in Jessore mustard field than Khulna which laid the pest population of thrips and whiteflies down in Abhaynagar, Jessore relative to Rupsha, Khulna. It was also recorded that temperature in Jessore was relatively lower than Khulna that might optimize, and favor the predators' richness as well as their preying efficiency resulting comparatively lower richness of pest population, thrips and whiteflies in Jessore relative to Khulna. 


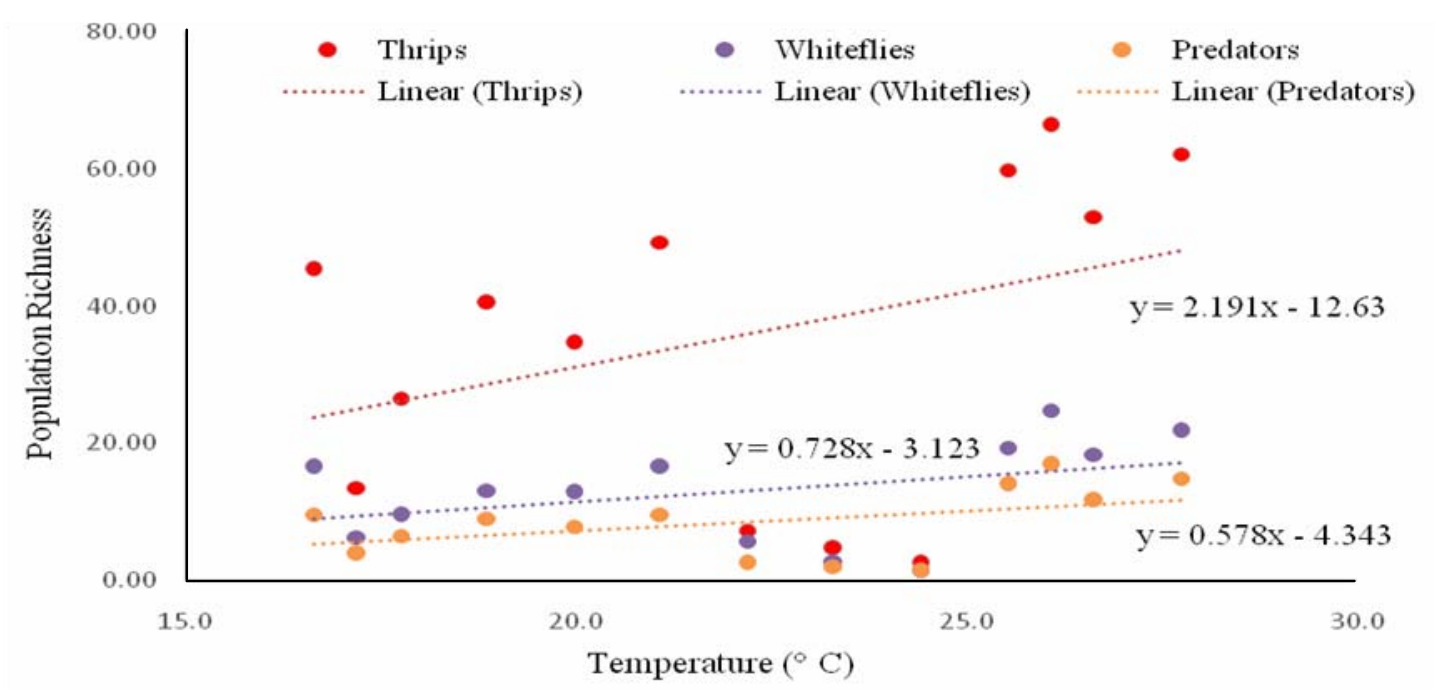

Fig. 2. Effect of temperature $\left({ }^{\circ} \mathrm{C}\right)$ on the population richness of insects in Jessore Region

\section{Seed yield and biological yield}

Genotype BARI Sarisha 16was grown both in Rupsha, Khulna and Abhaynagar, Jessore from Novenber, 2015 to March, 2016 with variable temperature and relative humidity. Sucking insect pests, thrips and whiteflies, and their predatory insects, Asian lady bug beetle and Geocoris bug were noticed from vegetative stage to reproductive phase in both mustard fields to maintain balanced agro ecosystems. As a result, there were no need to apply the synthetic insecticides to control them. The genotype BARI Sarisha 16 produced significantly higher seed yield $\left(1365.75 \mathrm{~kg} \mathrm{ha}^{-1}\right)$ in Jessore relative to Khulna $\left(1277.15 \mathrm{~kg} \mathrm{ha}^{-1}\right)$ and similarly biological yield was statistically greater in Jessore $\left(12573.12 \mathrm{~kg} \mathrm{ha}^{-1}\right)$ than that in Khulna(12131.25 kg ha ${ }^{-1}$ ) (Fig. 3). Similar pattern was also recoded for plant yield to be significantly higher in Jessore (25.99 gplant $^{-1}$ ) compared to Khulna (22.59 gplant ${ }^{-1}$ ) (Fig. 4). The result explored that mustard yield was significantly different between Rupsha, Khulna and Abhaynagar, Jessore primarily due to variation in population abundance of thrips and whiteflies, and their predators along with difference in ecological factors especially temperature $\left({ }^{\circ} \mathrm{C}\right)$.

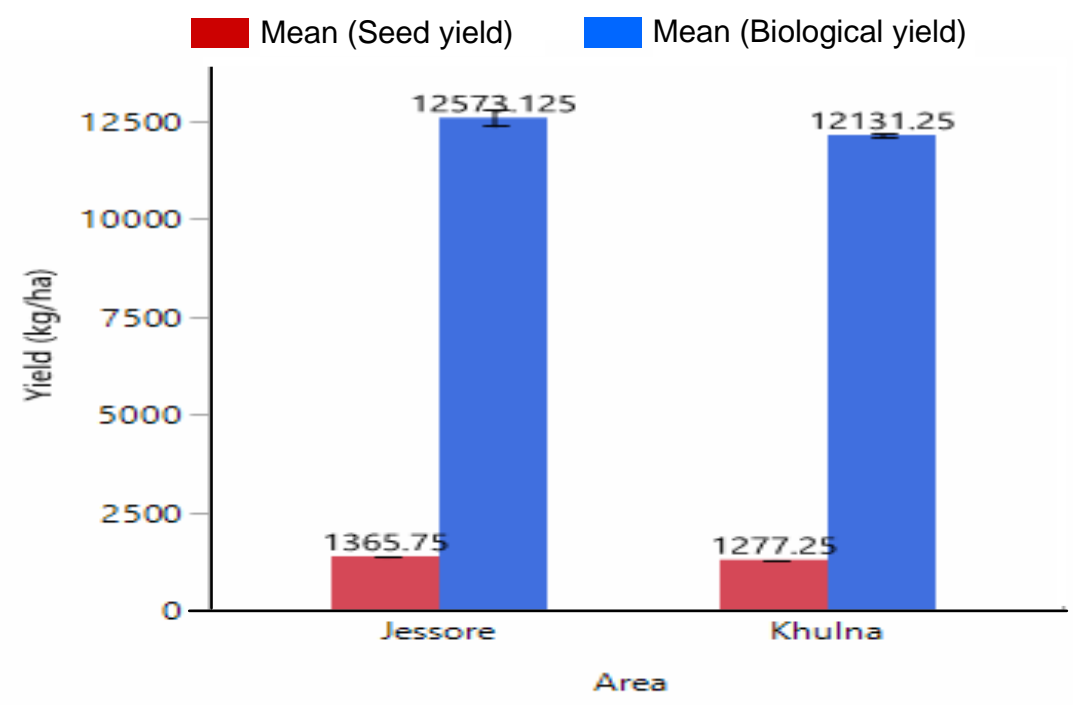

Fig. 3. Seed yield and biological yield of BARI Sarisha 16 in Rupsha, Khulna and Abhaynagar, Jessore ( $t$ ratio for seed yield $=9.52$ and $t$ ratio for biological yield=2.11; $p<0.001)$ 


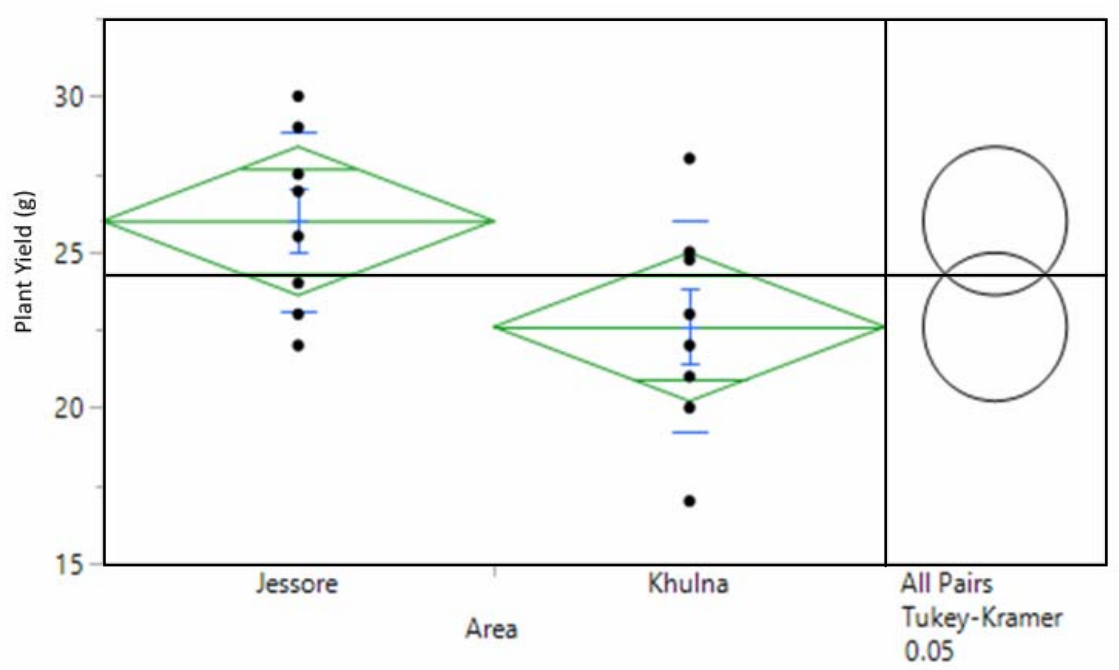

Fig. 4. Average individual plant yield (g) of BARI Sarisha 16 in Rupsha, Khulna and Abhaynagar, Jessore (t ratio $=2.16$, significant at 0.05 level)

\section{Conclusion}

In the present study, the population abundance of thrips and whitefly (Bemisia spp.), and their predators, Asian lady bug beetle and Geocoris bugon Brassica crops as well as Brassica yield were estimated in two separate locations of Bangladesh, Rupsha, Khulna and Abhaynagar, Jessore. The results revealed that temperature had a great influence on the population richness of insect pests and predators. The higher population abundance of all insects, pests and predators were statistically higher from February last to mid-March when the temperature varied from $25-27^{\circ} \mathrm{C}$. By contrast temperatures were relatively low from December, 2015 to January, 2016 ranging from more or less $16-20^{\circ} \mathrm{C}$ when insect population richness was also low. Comparatively lower pest population and higher predator population in Jessore compared to Khulna ultimately gave rise to higher Mustard yield in Jessore relative to Khulna.Therefore, seasonal abundance of insects predominantly relies on ecological factors particularly temperature that could make a distinction in crop yield as a whole.

\section{References}

Awmack, C.S. and Leather, S.R. 2002. Host plant quality and fecundity in herbivorous insects. Annual review of entomol. 47(1): 817-844.

Bale, J.S., Masters, G.J., Hodkinson, I.D., Awmack, C., Bezemer, T.M., Brown, V.K., Butterfield, J., Buse, A., Coulson, J.C., Farrar, J. and Good, J.E. 2002. Herbivory in global climate change research: direct effects of rising temperature on insect herbivores. Global Change Biology. 8(1):1-16.

Bangladesh Bureau of Statistics (BBS). 2015. Yearbook of Agricultural Statistics, Bangladesh, Statistics and Informatics Division. Ministry of Planning, Govt. People's Republic. Bangladesh, pp. 116-120.

Bjorn, G.K. 1995. Varieties of winter white cabbage. SP-Rapport-Statens-Planteavlsforsog. 13: 39.

Deligeorgidis, P.N., Ipsilandis, C.G., Vaiopoulou, M., Kaltsoudas, G. and Sidiropoulos, G. 2005. Predatory effect of Coccinella septempunctata on Thripstabaci and Trialeurodes vaporariorum. J. Applied Entomol. 129(5):246-249.

Dixon, A.F.G. 2000. Insect predator-prey dynamics: ladybird beetles and biological control. Cambridge University Press.

Food and Agriculture Organization (FAO). 2011. FAOSTAT database of Agriculture (Crops).

Furlong, M.J., Ju, K.H., Su, P.W., Chol, J.K., II, R.C. and Zalucki, M.P. 2008. Integration of endemic natural enemies and Bacillus thuringiensis to manage insect pests of Brassica crops in North Korea. Agric. Ecosys. Environ. 125(1):223-238.

Liu, T.X. 2000. Population dynamics of Bemisia argentifolii (Homoptera: Aleyrodidae) on spring collard and relationship to yield in the lower Rio Grande valley of Texas. J. Econ. Entomol. 93(3):750-756.

Malik, S., Jabeen, T., Solangi, B.K. and Qureshi, N.A. 2012. Insect pests and predators associated with different mustard varieties at Tandojam. Sindh University Res. J. (SURJ) (Science Series). 44(2). 
Mallik, M.S.A. 2013. Quality seed production of oilseed crops: An overview. Paper presented in the workshop on 'Modern Techniques for Quality Seed Production of Oilseed Crops'. Oilseed Research Centre, Bangladesh Agril. Res. Inst. Joydebpur, Gazipur.

Messelink, G.J., van Maanen, R., van Steenpaal, S.E. and Janssen, A. 2008. Biological control of thrips and whiteflies by a shared predator: two pests are better than one. Biological Control. 44(3):372-379.

Miah, M.A.M., Akter, M.,Khurram, M.M.M.H., Salam,M.A. and Uddin, M.A. 2010. Adoption of BARI mustard technology in selected areas of Bangladesh. Eco-friendly Agric. J. 3(2): 123-130.

Murai, T. 2000. Effect of temperature on development and reproduction of the onion thrips, Thripstabaci Lindeman (Thysanoptera: Thripidae), on pollen and honey solution. Appl. Entomol. Zool. 35(4): 499-504.

Nault, B.A., Shelton, A.M., Gangloff-Kaufmann, J. L., Clark, M.E., Werren, J.L. and Cabrera-La Rosa, J.C. 2006. Reproductive modes in onion thrips (Thysanoptera: Thripsidae) population from New York onion fields. Environ. Entomol. 35: 12641271.

Ramsey, A.D. and Ellis, P.R. 1994. Resistance in wild brassicas to the cabbage whitefly, Aleyrodesproletella. In ISHS Brassica Symposium-IX Crucifer Genetics Workshop. 407:507-514.

Ramsey, A.D., Ellis, P.R., Dias, J.S., Crute, I. and Monteiro, A. A. 1996. Resistance in wild brassicas to the cabbage whitefly, Aleyrodidesproletella. Int. Symposium on brassicas. Ninth Crucifer Genetics Workshop, 15-18 Nov., 1994. Lisbon, Portugal. Acta Hort. 1996; 507-514.

Sentis, A., Hemptinne, J.L. and Brodeur, J. 2012. Using functional response modeling to investigate the effect of temperature on predator feeding rate and energetic efficiency. Oecologia. 169(4):1117-1125.

Syed, T.S., Khanzada, M.S., Rani, S., Khanzada, G.H.A., Salman, M., Sarwar, M., Dayo, S.H., Anwar, S. and Su, W., 2016. Population dynamics of thrips, whiteflies and their natural enemies on mustard (Brassica campestris L.) Crop in different localities of Sindh, Pakistan.J.Entomol. Zool. Studies. 4(1): 7-16.

Wang, K. and Tsai, J.H. 1996. Temperature effect on development and reproduction of silverleaf whitefly (Homoptera: Aleyrodidae). Annals of the Entomological Society of America. 89(3): 375-384. 